\title{
The Foundations and Reasons of County Administrated by Province Reform: Analysis Based on County Economy and People's Livelihood Perspective
}

\author{
Xiaoqian Liu \\ School of Economics \& Management, Chengdu Technological University, Chengdu, China \\ Email: ganjin888@163.com
}

How to cite this paper: Liu, X.Q. (2018) The Foundations and Reasons of County Administrated by Province Reform: Analysis Based on County Economy and People's Livelihood Perspective. Modern Economy, 9, 1898-1907.

https://doi.org/10.4236/me.2018.911119

Received: October 22, 2018

Accepted: November 17, 2018

Published: November 20, 2018

Copyright $\odot 2018$ by author and Scientific Research Publishing Inc. This work is licensed under the Creative Commons Attribution International License (CC BY 4.0). http://creativecommons.org/licenses/by/4.0/

\begin{abstract}
In the process of the further transferring of economic and social development space to the counties in China, the County Administrated by Province Reform takes the important responsibility of solving the problem of improving the county economic performance and improving people's livelihood security system of counties. Based on this, this paper investigates the Chinese reform of the financial system under the province from two aspects: the basis of the operation of the county administrated by province and the main motivation of the reform. The study finds that the county administrated by province reform is a reform based on county-level government. The fundamental reason is that the deficiency of system changes causes the county-level government's expenditure responsibility to be inconsistent with its income, and the huge financial pressure is difficult to support the county's effective and balanced development.
\end{abstract}

\section{Keywords}

The County Administrated by Province Reform, County Economy, County Livelihood, County Administration

\section{Introduction}

Over the past 30 years of the reform and opening up, China's county society and economy has undergone a tortuous process of development and taken certain achievement. On the process of further transferring of economic and social development space to the counties, how to solve the financial dilemma at the county level, to stimulate the vitality of county economic development, and improve the 
livelihood security system at the county level have become the core content of the financial system reform under the province level. In the exploration and practice of the financial system reform under the provincial level, "the county administrated by province reform" has become a major breakthrough to improve the county economy and people's livelihood in recent years, since 2002.

From the point of view of the strategic intention of the county administrated by province reform, the most direct object involved is "county administration", which aims to solve the financial expenditure pressure caused by the mismatch of financial resources and responsibilities in the operation of "county administration", and the imbalance between the economic development of county and the improvement of people's livelihood. Therefore, the important basis of studying the county administrated by province reform is to understand the basic position of county-level regimes in the vertical intergovernmental relations, and the important motive of the reform is to examine the "emphasis on GDP growth while neglecting people's livelihood" formed by the pressure of county-level finance from the perspective of decentralization. This paper intends to analyze the reform of the financial system from these two aspects, and further explore the resulting problems of county economy and people's livelihood.

There search significance of this paper lies in taking the growth-type incentive mechanism which affects the promotion of officials as the institutional background, hackling how the governance model of the county administrated by province adjusts the power allocation among local governments brought about by the decentralization pattern below provincial level. This paper not only enriches the relevant theoretical research, but also provides practical guidance for the reform. After a brief introduction at the first part, the article discusses the existing researches in the second part. In the third part, the important foundation of county administrated by province reform is thoroughly analyzed. In the fourth part, the article analyzes the motivation of reform from two aspects of subjectivity and objectivity. Finally, the conclusions and research suggestions are given as ending.

\section{Literature Review}

The financial difficulties of counties and townships accompanied by fiscal decentralization in China mainly lie in the fact that there has not been a functional fiscal system of tax distribution under the provincial level. Therefore, the county administrated by province reform which seeks a development breakthrough flattening of the financial system has gradually risen to an important position. This is also a decentralization reform at the county level aimed at clarifying the power and responsibility relations among governments below the provincial level, because the fundamental to strengthen the government's macro-control is to solve various problems during the development, at the help of deepening the adjustment of the financial system and straightening out the inter-governmental relations (Li Meng, 2012) [1].

Among the studies on the effect of the county administrated by province 
reform on County economy, some hold basically attitude to the reform ( $\mathrm{Yu}$ and Wang, 2014; Sun Yongjie, 2016) [2] [3]. In further analysis, some studies have found that in the decentralization reform toward county level, "expanding the power and strengthening the county" not only promotes the county economic growth, but also has a positive effect on the market-oriented reform (Yuan and Zuo, 2011) [4]. The effect of "expanding the power and strengthening the county" on economic growth is superior to "direct financial management" (Cai and Huang, 2010) [5]. The economic growth brought by the reform mainly comes from economic decentralization (Zheng Xinye, 2011) [6].

The county administrated by province reform has significantly improved the level of fiscal decentralization and deepened the degree of economic and fiscal decentralization among provinces, cities and counties by giving county government greater financial power and economic management authority, but the impact on people's livelihood is uncertain.

Some scholars believe that the county administrated by province reform is beneficial to improve the level of county-level public services and improve the backward situation of county-level public services to a certain extent (Chen and Lu, 2014; Yang Liangsong, 2016; Wang and Li, 2018) [7] [8] [9]. However, more scholars believe that the county administrated by province reform has further aggravated the distortion of the expenditure structure at the county level. Multi-dimensional measurement based on panel data of Hebei Province shows that the reform has led to further distortion of the supply structure of county public goods (Liu et al. 2012) [10]. Tan et al. (2015) pointed out that the county administrated by province reform not only improved the income gap, education, social assistance and other livelihood conditions between urban and rural areas, but also significantly improved the level of fiscal decentralization at the county level, based on a sample of 21 provinces in China [11]. Jia and Ning (2015) investigated the national county-level panel data, the results show that the financial system reform of the county administrated by province restrains the public services of people's livelihood in general [12].

In a word, the existing studies have not discussed the formation of financial pressure in county-level from the historical position of the county system, nor have they made a strong analysis from the subjective and objective levels. This study intends to make up for this deficiency.

\section{The Foundation of the County Administrated by Province Reform: Perspective Based on the County Level}

\subsection{Historical Position of County System}

The county administrated by province reform is a reform involving administrative system at county level. The administrative system of a county is the key to the continuity and long-term survival of the county system, and foundation of the legalization and institutionalization of the county system. As the basis of the operation of China's administrative system, the county system is the most basic 
unit for the state to rule and manage, and its administrative system has rarely undergone major change in history. Historically, although the county's administrative division, institutional settings and so on changes, the county's administrative system has always been stable and continued in the dynastic changes, as basic state power established by the central government, it's clear that its basic status is beyond doubt and has been tested.

Since the appearance of county system, the county government was in the "contractor" status of the vertical administrative system in the feudal society, which has been inherited to present county administration largely. The core responsibility of the county government in China has always been to manage affairs and provide public services in the face of the vast rural areas, which is the administrative and financial basis for the rule of authoritarian countries. From the late Qing Dynasty to the Republic of China, the power structure and the institutions establishment of government tended to specialization, and the county administration gradually transformed to modernization, such as the expansion of the supply scope of public goods at the county level, the transformation from traditional education to public education, and so on. The modernization of county administration in China has not stopped until now, and this process has been devoted to the construction of fiscal and taxation absorptive capacity and political resource control capacity. The historical evolution of county administration has an enlightening role in studying the current administrative and financial expansion of the county. What cannot be ignored is that even though the county government has been focusing on the modernization construction, the institutional inertia of the county system still affects the present county structure, County construction, and the social and economic development of the county.

\subsection{Contemporary Status of County System}

After the founding of New China, although the state grassroots power sinks to the township, the county-level political power retains governance function of grassroots political power in many aspects. The main reason is that in the county and township regimes, the principles of the constitutional design of the state are basically practical for the construction of county-level regimes, virtual for the construction of township regimes, and there is no decision-making body in township government in the real sense. Therefore, in the background of the county administrated by province reform, the county system is still an important part of the local administrative system, which directly reflects the relationship between governments and the state's public management functions at the grass-roots level, and even can be called the "miniature" of the central will at the local level. The reform of county system is often an adaptive adjustment for the transformation of economic and social development. Although it is far less severe than the adjustment of the relationship between the central and local governments, it can drive the development of county economy and society lagging 
behind relatively while the basic fiscal and taxation system remains unchanged, and further rationalize the powers and responsibilities between governments below the provincial level at the same time while avoiding system concussion brought about by the reform.

In contemporary society, the county government is still in the position of "contractor" in the vertical intergovernmental relations, which is also the key breakthrough to study how to revitalize the county economy through the county administrated by province reform. Dr. Feng Junqi of Peking University (2011) pointed out in a survey of a county in Henan Province that the task indicators issued by the government from the top to the bottom are almost identical from the provincial to the city, then to the county and finally to the township [13]. The political achievement chain with the characteristics of pressure-based decentralization has formed a "political achievement isomorphism" with Chinese characteristics in the transmission of power and responsibility from top to bottom. In this political achievement chain, the superior government stimulates the "political achievement" of the lower government through its own advantageous position at the government level, by means of the administrative decentralization system and the promotion incentive mechanism of officials. This phenomenon leads to the fact that the lower government is usually only responsible for the superior government directly leading it. However, because of the increasing agency costs caused by the large gap between the central and local governments, the decrees transmitted by the central government to the lower government will be gradually reduced and the binding force of the central policy will be gradually reduced at the vertical level. Moreover, the county government is at the bottom of this "political achievement chain", many policies of the central government repeatedly reiterated are difficult to implement at the county level in fact, and many problems have arisen, including the abuse of extra budgetary funds, the heavy debt of counties and townships, and the rural arbitrary charges caused by "eating finance" in county-level.

\section{The Main Motivation of Reform: The Expenditure Responsibility and Pressure Source of County}

\subsection{Analysis Based on Subjective Level}

In view of the administrative contract system characteristics of the vertical inter-governmental in China, the superior government often gives the sub-national government greater authority in the process of contracting. At the same time, because of the high reconstruction and overlapping of the functions of the vertical inter-governmental agencies, the county government is the ultimate contractor of the "contract issuing" affairs of the central, provincial and municipal governments step by step. The responsible person of the county government is not only the centralizer of the local regime, but also the ultimate responsible person for the above affairs. This kind of contracting system is accompanied by the obvious characteristics of pressure-style decentralization. For 
the grassroots government and its responsible people, while obtaining larger administrative resources, they also have to bear a large number of business responsibilities, both power and responsibility coexist.

The quasi-grassroots status of county administration reflects the distinct decentralization characteristic of "downward shift of responsibilities" in vertical administrative system in China, whether it is the contracting party responsible for the lower township or the contractor of the higher level. It is undeniable that the pyramidal supervision system also greatly saves the cost of information transmission, and facilitates the central government to conduct effective vertical management directly. Although this management mode can be well maintained and operated by the "political championship" type of incentive mechanism for promotion of officials, the higher level government has put down social, economic, cultural and other development responsibilities to the county government as bargaining chip of official promotion and performance appraisal, resulting in serious inconsistencies between the expenditure responsibility and income of county government.

From 1993 to 2010, the overall performance of county fiscal self-sufficiency shows that, influenced by the county administrated by province reform in 1994, the county fiscal self-sufficiency rate dropped sharply from 0.778 in the previous year to 0.447 , and has been at a low level since then. In the 16 years from 1994 to 2010, the average financial self-sufficiency rate at the county level was only 0.469 , which indicates that the financial self-sufficiency at the county level is weak and the financial gap is large.

In summary, on the subjective level, this system stimulates county government officials, who are at the end of the vertical intergovernmental relationship, to constantly focus on the performance appraisal indicators set by the higher government in situation that the county-level fiscal continually tighten, such as GDP growth rate and other indicators which can be quantified and achieved in the short term, but continuous neglect county's social development, livelihood security and other historical debts, which are more difficult to achieve immediate results.

\subsection{Analysis Based on Objective Level}

While the downward shift of responsibilities, China's pressure-style decentralization system not only implies the characteristics of "political performance isomorphism" and the corresponding "political championship" mechanism, but also accompanies the objective level of "responsibility isomorphism," and has become an important factor affecting the operational efficiency of grass-roots governments

Compared with the central, provincial, and municipal governments, county-level governments are the first-level governments directly facing the urban and rural areas under their jurisdiction, and naturally assume the functions of urban and rural public service supply within the county. According to Article 107 of the Constitution of the People's Republic of China (2004), governments at 
or above the county level, within the limits of their jurisdiction prescribed by law, are required to undertake economic development, livelihood security, ethnic affairs, judicial and administrative work within their administrative areas. The single system state structure of China determines the high consistency of responsibilities, functions and institutional settings of governments at different vertical levels, and forms the basic characteristics of isomorphic responsibility. This paper summarizes the relationship of responsibility power, financial power, and financial resources by using charts (Table 1) among the provincial, municipal, and county governments. It can be found that the county government has almost the same responsibilities as the higher government in addition to its economic regulation and control functions. Table 1 is compiled according to the China Financial Yearbook.

There are provisions in paragraph 10 of article 59 of the law of the local people's organizations at various levels:

(1) To implement the resolutions of the people's congresses and their standing committees at the corresponding levels, as well as the resolutions and orders of the state administrative organs at higher levels, stipulate administrative measures, and issue decisions and orders.

(10) To handle other matters assigned by the superior state administrative organs.

From the provisions of the first and tenth paragraphs of this regulation, it is not difficult to see that under single system state structure of China, the vertical

Table 1. Responsibilitypower, financial power, and financial resources among the provincial, municipal, and county governments.

\begin{tabular}{|c|c|c|c|c|}
\hline & Item & Province & Municipality & County \\
\hline \multirow{8}{*}{$\begin{array}{l}\text { Responsibility } \\
\text { power }\end{array}$} & Economic regulation & $\bullet$ & $\circ$ & - \\
\hline & Infrastructure construction & $\circ$ & $\bullet$ & $\bullet$ \\
\hline & Environmental protection & $\bullet$ & $\bullet$ & $\bullet$ \\
\hline & Education & $\circ$ & $\bullet$ & $\bullet$ \\
\hline & Medical and health & $\circ$ & $\bullet$ & $\bullet$ \\
\hline & Culture and physical training & $\circ$ & $\bullet$ & $\bullet$ \\
\hline & Public safety and justice & $\circ$ & $\bullet$ & $\bullet$ \\
\hline & Social security & $\bullet$ & $\bullet$ & $\bullet$ \\
\hline \multirow{4}{*}{ Financial power } & Tax legislative power & $\bullet$ & ० & - \\
\hline & $\begin{array}{l}\text { Tax collection and } \\
\text { management right }\end{array}$ & o & $\bullet$ & $\bullet$ \\
\hline & Charge right & ○ & $\bullet$ & $\bullet$ \\
\hline & Debt right & ० & $\bullet$ & - \\
\hline \multirow{3}{*}{$\begin{array}{l}\text { Financial } \\
\text { resources }\end{array}$} & Tax revenue & $\bullet$ & $\bullet$ & $\bullet$ \\
\hline & Transfer payment & $\bullet$ & ० & $\bullet$ \\
\hline & Non tax revenue & ० & $\bullet$ & $\bullet$ \\
\hline
\end{tabular}

Note: • Main responsibility; ○ Secondary responsibility; - Non responsibility. 
inter-governmental relations strictly follow the hierarchical principle set by bureaucracy. The superior and subordinate governments show obvious characteristics of leading and being led, as well as absolute "upward responsibility" and "obeying the superior". While the Constitution lists the responsibilities of local governments, each of which mentions "handle other matters handed over by the higher state administrative organs" without exception, which shows that the functions of the provincial, municipal and county governments are highly homogeneous. Combined with the characteristics of the responsibilities isomorphism, the local government should be responsible for all administrative work in the region, and must be responsible for the higher-level government. However, the responsibility authority is lack of clear legal basis and detailed norms, so it is difficult to avoid the responsibility power would be shifted from top to bottom and finally to the county government without reservation. Due to the lack of reasonable and effective division of labor among inter-governments, the superior government has an absolute advantage in the distribution of resources and power, while the lower government will hardly break through the restrictions of this right system. In addition, it is difficult for the township government to assume the responsibility of the first-level government, the "power shift down" characteristics in vertical administrative system are almost completely reflected in the development and reform process of the county government in recent years. After the tax-sharing reform, especially after the system of tax distribution, the development trend of the inter-governmental power structure has only evolved from the vertical centralization mode of the unification of administration and finance to the hierarchical decentralization of fiscal revenue and expenditure and the centralization mode of administrative norms and appointment and removal of officials (Wang Xiaolong, 2004) [14]. In essence, the relationship between the grass-roots governments at the county level and the superior governments is a multi-task "principal-agent" relationship, but the specific functions of the county-level regime at the bottom of the relationship are vague and unregulated.

In a word, on the objective level, the county-level government is faced with multi-task entrusted responsibilities, and because of the collection of financial power and the disguised exploitation of the municipal government under the "city governing county", the county-level regime not only shoulders the most heavy responsibility, but also lacks stable financial resources. So the county-level government is naturally difficult to develop, and unable to ensure the implementation of "three agriculture", medical and health, education, publicsecurity, social security, employment and other issues within the territory.

\section{Conclusion and Suggestion}

Based on the above analysis, the study first found that the County Administrated by Province reform involves the redistribution of powers and responsibilities of the governments below the provincial level at the vertical level. While taking 
county government as the basis of reform, it is also a financial system reform below the provincial level which involves the improvement of the contractor status of the county level government. At the same time, the study finds that the fundamental reason for the County Administrated by Province reform lies in the inconsistency between the expenditure responsibility of the county government and its income resulting from the insufficiency of the institutional change, and the huge financial pressure is difficult to support the effective and balanced development of the county. The existing financial and administrative system has led the county government to "emphasize GDP instead of people's livelihood."

In order to implement the county administrated by province reform smoothly and steadily, this study puts forward the following suggestions. First, it is necessary to give the county government more practical management authority, on the basis of clarifying the division of financial power, administrative power and financial resources among governments at or below the provincial level. Secondly, it is necessary to cultivate the ability of grassroots governments to solve the actual financial difficulties, further expand the effect scope of fiscal revenue decentralization in enhancing the financial capacity of grassroots governments, properly expanding the tax power of county governments while actively promote the establishment of the system of tax distribution within the province. Finally, it is necessary to clarify the responsibility of government expenditure at all levels. In the fiscal system reform under the provincial level, we should further define the boundaries of the responsibility of government expenditure at all levels according to the vertical government level, to achieve the "heterogeneous responsibilities" among different levels of government.

\section{Conflicts of Interest}

The author declares no conflicts of interest regarding the publication of this paper.

\section{References}

[1] Li, M. (2012) Economic Influence of the County Administrated by Province Reform. Economist, 3, 55-58.

[2] Yu, H. and Wang, Q. (2014) Path Selection in Deepening Fiscal Reform of "County Governed by Province". Contemporary Finance \& Economics, 5, 004.

[3] Sun, Y.J. (2016) Has the County Administrated by Province Promoted the Regional Economic Growth?-Evidence From the County Economy of Henan Province. Sub National Fiscal Research, No. 8, 47-52.

[4] Yuan, Y. and Zuo, X. (2011) Enlarging Power and Strengthening Counties" and Economic Growth: Microscopic Evidence of Industrial Enterprises Above Designated Size. The Journal of World Economy, No. 3, 89-108.

[5] Cai, G.W. and Huang, L.X. (2010) The Influence Factors and Economic Performance of Government Level Reform. Management World, No. 8, 73-83.

[6] Zheng, X.Y., Wang, H. and Zhao, Y.Z. (2011) Can the County Administrated by Province Promote Economic Growth?-Double Difference Method. Management World, No. 8, 34-44+65. 
[7] Chen, S.X. and Lu, S.F. (2014) Did Decentralization Increase Financial Expenditure for the People's Livelihood?-A Natural Experiment from the County under the Direct Administration of the Province of China. China Economic Quarterly, No. 3, 1261-1282.

[8] Yang, L.S. (2013) China's Fiscal Decentralization and Local Education Supply. Journal of Public Administration, 6, 104-134+180-181.

[9] Wang, D.X. and Li, J.J. (2008) The Impact of Population Scale and County Administrated by Province on Local Public Goods Supply: Empirical Evidence from the Data of Hubei Province at City and County Levels. Statistical Research, No. 12, 15-21.

[10] Liu, J., Wu, J.N. and Wu, J.S. (2012) The Influence of the County Administrated by Province Reform on the Supply of Public Goods in County Areas: An Empirical Analysis Based on the Panel Data of 136 Counties (Cities) in Hebei Province. Comparative Economic \& Social Systems, No. 1, 35-45.

[11] Tan, Z.B., Zhou, L. and Zhao, Y. (2015) The County Administrated by Province Reform, Fiscal Decentralization and People's Livelihood-Estimation Based on “Multiple Difference Method”. China Economic Quarterly, No. 3, 1093-1114.

[12] Jia, J.X. and Ning, J. (2015) Longitudinal Financial Governance Structure and Local Government Function Optimization-Based On the Quasi-Natural Experimental Analysis of Fiscal System Reform In County Administrated by Province. Management World, No. 1, 7-17+187.

[13] Feng, J.Q. (2011) Investigation of "Political Clan" Phenomenon in Zhong County. Southern Weekly, 2011-09-01(B09).

[14] Wang, X.L. and Fang, J.J. (2015) Financial County Administrated by Province Reform and Tax Exemption from Grassroots Government. Economic Research Journal, No. 11, 79-92. 